\title{
Collaboration Policy Of Regional Office Of National Anti-Narcotics Agency With Local Wisdom (Perarem Desa Pekraman) In Bali Handling Drug Abuse
}

\author{
I Made Sumada \\ Master of Administration Study \\ Program \\ Ngurah Rai University \\ Bali, Indonesia \\ sumadaimade@gmail.com
}

\begin{abstract}
Based on the policy of drug abuse as regulated by Law No 35 of 2009 concerning Narcotics. Drugs abuse lately has been a problem faced by Indonesian. As recorded, the drugs abuse is not only found in adults but also in younger generations of Indonesia. In 2014, the drug abuser in Indonesia reached 4.022.702 people, of which 2.01 percent in Bali or as many as 61.353 people in 2018 . To prevent drug abuse upon young generation, so there should be a collaboration with local wisdom of Bali to be inserted into Perarem, Pekeraman. Perarem is customary village rules that are in form of village meeting decision. This study was conducted in Bali Office of National Anti-Narcotics Agency. This research used qualitative descriptive research method, with data collection technique of a direct interviews to the informant or source in order to find data about policy collaboration between Perarem, Pekeraman in preventing and handling drug abuse in Bali Province in 2018 , and then, interview head of Bali Office of National AntiNarcotics Agency. The data analysis was qualitative analysis in which the data were classified, pictured into words or sentences based on the category to draw the conclusion. In order to minimize the drugs circulation and abuse in Indonesia, especially in Bali, this effort should be done not only by government, which is represented by BNNP or BNNK but also all people. For preventive effort, there should be collaboration between BNNP with local wisdom such as a customary village which has legal product called as awig-awig or pararem because these legal products contain sanction for the abuse, in which the most severe punishment is kesepekang (expelled from the village).
\end{abstract}

Keywords-Collaboration, policy, and local wisdom

\section{INTRODUCTION}

Statement of Jokowi, The President of Republic of Indonesia on the Limited Meeting on 24 February 2016, confirmed that Indonesia is in an Emergency Situation of Narcotics. Drugs affects brain system and has addiction risk. If it is not used properly, it will endanger the user. The addiction effect of the drugs will make the user to be addicted and keep using it. The use of drugs in long term will affect the internal organ and the body will keep asking for more dosage. If the drug is consumed overdosed, it will cause death.

Presently, drugs abuse in Indonesia is apprehensive, which is proven by the emerging number of drugs users in all communities. Drug is easily obtained by adults, teenagers even children. It is pity since they are the future of this nation. Adolescence is a transition period; a human transition from children to be adults.

In this transition period, the mental state of the teenagers is not stable. They are easily influenced by negative things, including tempted to try drugs. In some cases, in the beginning the drugs abuse only try to use, curious of using it. However, the nature of drug compound that can cause addiction make the users to be addicted. Further, based on data from Indonesian Child Protection Commission (KPAI) recorded that from 87 million population of Indonesian children, 5.9 million of them are drugs abusers because of influence from close relationship people (Health Issue Commissioner of KPAI, 6/3/2018). Bali Office of National Anti-Narcotics Agency records that drugs abusers in Bali reaches $2.01 \%$ of the total population or 61.353 people. Most of the abusers are from productive aged people, i.e. 21-40 years old, while the total of abusers outside of the productive aged people not more than $1 \%$.

To prevent drug abuse, especially in Bali, there are some socializations that have been conducted about the danger of drugs into schools from elementary until university level in the period of students' registration. The Head of Bali Office of National Anti-Narcotics Agency gave seminar to the students of KKN PPM Period XVII in Udayana University (26/6/2018), and BNN Bali signed up for Memorandum of Understanding with local government of Karangasem to fight drugs abusers among Civil Servants (23/6/2018). All kinds of efforts that have been carried out by the Head of BNNP Bali in an effort to combat drug abuse but have not produced maximum results, such as previous research conducted [1] explained that Efforts to overcome problems related to drug abuse have not been carried out effectively. The Indonesian 
government still behaves ambiguously to deal with the problem of drug abuse. To reduce the spread of HIV / AIDS among IDUs, some institutions offer syringe and bleaching exchange programs, where the government has not been chosen to support them. Further reference [2] the most dominant factor that causes drug abuse in teenagers is due to social factors, this is based on the conclusions of the results of direct interviews with informants stating that the factors of association with peers are too free and uncontrolled causes teenagers to fall into drug abuse. In order for adolescents not to fall into drug abuse the role of parents is urgently needed by further increasing supervision of the behavior of their family members, parents are also expected to always take the time to always be by their children in any condition, so that teenagers do not fall for things those who deviate, especially drug abuse. In addition, there is a need for good cooperation by all elements, both government and society, so that drug abuse among adolescents can be prevented as early as possible. Further research conducted from reference [3] states that drug problems in Indonesia are still something that is urgent and complex. In the past decade, this problem has become widespread. Evidenced by the increasing number of drug abusers or addicts significantly, along with the increasing disclosure of drug crime cases that are increasingly diverse patterns and increasingly massive syndicate networks. Indonesian people, even the world community, are generally faced with a situation that is very worrying due to the illegal use of various types of drugs. This concern is increasingly sharpened due to the rampant illicit drug trafficking that has spread in all walks of life, including among the younger generation. This will greatly affect the life of the nation and the country in the future. The behavior of some adolescents who have clearly far neglected the values of norms and norms and laws that apply in the midst of people's lives is one of the causes of rampant drug use among the younger generation. In everyday life in the midst of society there are still many teenagers who still commit drug abuse. Likewise, the results of research conducted reference [4] stated that the factors that cause adolescents to abuse drugs among family factors that pay less attention to their children, as well as environmental factors can also have a major effect. With education and religious education is the outer wall preventing drug abuse. However reference [5] said that formal and informal relations between citizens or companies were very intensive. International crimes that cross national jurisdictions have increased in sophisticated forms and frequency is increasing. Because increasingly progressive international vices are needed for more coordinated cooperation between countries as law enforcement. The Reciprocal Legal Assistance Agreement (MLATS) arises because the eradication of inadequate crime is enforced by an extradition agreement. The Form of Reciprocal Legal Assistance Agreement (MLATS) has been agreed upon, for example the United Nations Convention Against Corruption in 2003, United Nations Conventions Against Organized Transnational Crime in 2000. While at the ASEAN level, Mutual Assistance in Legal Aid Agreement in Criminal Problems year 2004

From some of the studies conducted above, no one has discussed the collaboration between the National Narcotics Agency's policy with Local Wisdom (Perarem Pekraman Village) in Bali in handling drug abuse, the purpose of this study is to find out how drug abuse in Bali has not been maximized. To support us, we use the collaboration method between local wisdom in hopes of reducing drug abuse.

\section{METHOD}

\section{A. Research Approach}

The approach of this research is qualitative descriptive analysis method by taking location in Bali province, and used primary and secondary data. The data were collected through interview informant that had been determined through purposive sampling.

\section{B. Technique of Analysis}

Technique of analysis in this qualitative research included (1) data reduction, which means collecting data through interview the informant, collecting library materials, after the collection, the data were managed by selecting and clarifying logically and systematically; (2) data presentation is presenting the data after the data were collected through interview and library research by explaining, describing, and picturing the concepts containing in this research, and (3) data verification. It is started from data collection process until data presentation. After that is drawing conclusion.

\section{RESULT}

\section{A. Collaboration}

Based on Law No 35/2009 Concerning Narcotics. Narcotics are compound/drugs from plants or not plants, both synthetic or semi-synthetic which can cause decrease or change of consciousness, the loss of pain, decrease until losing pain and generate addiction. According to reference [6], collaboration is a form of social process, in which there is certain activity aimed to reach mutual goal by helping and understanding activities of each other. Further, collaboration is defined as mutually working to reach mutual goal. It is the most basic social process. Usually, collaboration involves task division, in which everyone does his/her own task to reach the mutual goal.

Meanwhile, in administrative term, definition of collaboration as described in reference [7] is an effort to reach mutual goal that has been established through task/job division, which all of them are directed in reaching the goal. The effort in collaboration can be in form of: (1) Formal Effort. It means a purposeful, directed, planned and systematic effort. (2) Informal Effort. It means an activity which is done purposively but not planned and not systematic. This effort is done and developed to improve the efficiency and activity of the informal effort.

There are three kinds of cooperation (collaboration) based on the difference between group organization or in group attitude, i.e.: (1) Primary Collaboration. Here, the group and individual are definitely blended into one. Group contains all individual life, and each of them chase for each jobs, for the sake of all group members. For the example, daily routine activity in speaking, family life in primitive society and others [8]

In small groups such as family and traditional communicates, the social process of cooperation tends to be spontaneous. This is a natural cooperation in group formed 
which is called as primary group. In these groups, individual tends to blend each other in the group, and each of them try to be a part of the group. In this small and face-to-face primary groups, every person tends to work in team as a member of team rather than work as an individual [9]; (2) Secondary Collaboration. Characteristic of primary collaboration is primitive society, so secondary collaboration is typically modern society. This secondary collaboration is highly formalized and specialized, and each individual only dedicate a part of their life into the united group. These people are more individualistic and calculative. The examples are collaboration in trading offices, industries, government, etc. [10]; (3) Tertiary Collaboration. Here, the basis of collaboration is latent conflict. Attitude of the collaborative parties is purely opportunistic. It is a very loose and easily broken organization if the mutual tools no longer help every person in achieving their goal. The examples are relationship between company executive and labor, relationship of two parties in facing the third party [11].

According reference [12] Collaboration is the collection of knowledge, skills, values and motives applied by practitioners to translate the following into effective practice, in reference [13] collaboration is the essence of being an organization, it is a much wider concept than is traditionally discussed. The word "collaboration" in a business context has somehow shifted towards "how people work together within an organization."

In collaborating besides the importance of the organizations invited to do collaboration but more effective in its implementation, it is very much determined by cultural factors in reference [14] Awareness of different cultures, value systems and ethos can be of immense help in ensuring the growth of a collaborative global business. Learning to overcome cultural differences in a positive way can help collaborative businesses to flourish rapidly. At a fundamental level, culture is the ethos exuded by a group of people. Practically, it is the way members of an entire society live their lives. These members of the society are our consumers, managers, employees and governors. On a more formal level, according to an anthropological definition in reference [15]: "Culture is 'a system for creating, sending, storing and processing information." These definitions themselves seem to indicate that whenever different cultures try and intersect, there are bound to be differences. Culture refers to the total way of life - the underlying patterns of thinking, feeling and acting - of particular groups of people. It is learned, not inherited, and transmitted from generation to generation primarily through conditioned learning. Therefore, it does not come as a surprise, that collaborative global alliances face cultural disparities as one of their major challenges.

\section{B. The Reason or Background of Collaboration}

As cited by Abdulsyani, according to Charles Horton Cooley, collaboration arises if:

- People are aware that they have mutual interests at the same time have adequate knowledge and self-control to fulfill these interests through collaboration.

- The awareness of mutual interests and organization are important facts in beneficial collaboration [16]. Further, it is explained that basically collaboration may arise if someone or group of people could get benefit or usability from other person or group: and vice versa.

\section{Awig-Awig of Customary Village}

Awig-awig is a legal product of a traditional organization in Bali, which is generally made by consensus by all members and in effect to the members themselves. Therefore, awig-awig is attitude standard made by the people based on fairness and decency live in their society [17]. One of the traditional organizations authorizes to make awig-awig is customary village. Besides this village, there are some other organization authorize to make awig-awig such as subak (rice field farmer organization), subak abian (dry land farmer organization), and other social groups united in sekaa-sekaa, such as sekaa teruna (youth organiation), sekaa dadya (social group based on the same ancestor), and others.

Customary village is different with common village which is known as modern organization conducting legal administration of the state in village. This village is wellknown as official village to differentiate with customary village which conduct religious social function in the village. The existence of these two kinds of village emerged since colonial era, even the embryo can be traced back since the era of Bali-Majapahit kingdom in reference [18] and [19]. The government of customary village is held by prajuru adat lead by Bendesa, while government of official village is held by Village Government lead by Head of Village. The legal product of official village is called "Village Rules" and one of Indonesian rules and regulations, made and legalized by Head of Village with Village Consensus Agency [20]. The legal product of customary village is called as awig-awig desa pakraman and categorized as unwritten law in the system of Indonesian rules and regulations (customary law), which is made consensually by members of customary village through a paruman desa (village meeting).

Customary village is a unity of customary law society in Bali. Local Regulation No 3 of 2001 concerning Customary Village as amended with Local Regulation No 3 of 2003 clearly stated that in Article 1 Number (4) as: "Village Customary is a unity of customary law society in Bali Province which has a unity of traditions and manners of Hindus life through generations in the bounding of kahyangan tiga or kahyangan desa with certain area and wealth as well as has a right to manage their own household".

Written awig-awig commonly contains the subjects (main rules) concerning the life of customary village, while the detail implementing rules are described into pararem. In broader definition, awig-awig includes pararem, but sometimes they are not differentiated. In specific definition, pararem is defined as meeting decisions with bounding power. Concerning the substances, pararem can be defined into three categories. First, pararem penyahcah awig is a meeting decision which is implementing rules of awig-awig; second: pararem ngele/ detached pareram is a meeting decision which is a new rule without any basis of awig-awig but it is made to fulfill people law needs; third, pararem penepas wicara is a meeting decision about certain law suit (case), both in form of dispute or violation of law (pararem panepas wicara). 


\section{RESULT}

To prevent drug abuse in Indonesia, especially in Bali, there should be collaboration between government in this term of Regional Office of National Anti-Narcotics Agency, private sector and the people. The collaboration means through local wisdom, because Indonesia is very rich of diversity of culture, customs, race, religion but still in the frame of the Unitary State of the Republic of Indonesia based on Pancasila and Constitution 1945. Local wisdom in Bali is based on culture and religion, in which both religion and customs are a unity which cannot be separated based on customary village.

To run the government, the customary village uses customary law product in form of awig-awig or perarem, in which the implementation is only applicable in Bali and do not violate legal formal of Indonesia. Each customary village has their own awig-awig which are different each other, depending on the situation of the village. Awig-awig or perarem is the description of Tri Hita Karana philosophy. This philosophy becomes character of customary village which differentiates them from other customary law unities outside of Bali. This philosophy is derived from Hindus principle, which literally means the causes of prosperity (tri=three, hita=prosperity, karana=cause). These three elements are Sanghyang Jagatkarana (The Almighty God), Bhuana (universe), and manusa (human) [21]. Generally, this concept proposes that human prosperity in this world can only be achieved by balancing those three elements; God-HumanUniverse, i.e. as follows:

- Balance relationship among humans, both individually or in group.

- Balance relationship between human and the environment.

- Balance relationship between human and God.

The content of awig-awig is the description of the Tri Hita Karana concept itself which is described previously, i.e. concerning religious aspect or parhyangan (relationship between the villagers and God), social aspect or pawongan (relationship among villagers, both individually or in group), and aspect of territory or palemahan (relationship between villagers and their territory). Besides these three aspects, generally at the end of the awig-awig there is explanation of problem solving mechanism if there is violation of those three aspects. The Articles regulating these problems are stated in a different chapter entitled Wicara lan Pamidanda (Problem and Sanction) [22].

Sanction in awig-awig is called as pamidanda, aiming at restoring the balance if there is disturbance of the relationship in aspects of territory (palemahan), social (pawongan), and religion (parhyangan). This pamidanda in legal literature or widely-known in the society as customary sanction. Generally, form of this pamidanda (customary sanction) is divided into three categories, i.e. sanction related to property (money or valuable object) called as artha danda; sanction related to mental or physical agony called as jiwa danda; and sanction related to balance restoration of unseen natural force (niskala) called as panyangaskara danda. Form of sanctions from these three sanction categories are varied from minor into major sanction. Sanction form of artha danda is the most minor sanction, for instance fine of money or valuable objects which are called as dedosan, kebakatan, etc. while the major sanction is karampag (the property is confiscated to be sold and the result is used for paying off their obligation in the village). The minor sanction of jiwa danda is kagelemekin (reprimanded by the officer or in a meeting), meanwhile the major sanction is kasepekang (ostracized) and kanorayang makrama (fired as the member). Example of panyangaskara danda sanction is obligation of nyarunin desa (conducting sacred sacrifice to restore village purity).

Based on the previous description, Balinese people who are member of customary village are bounded into awig-awig or perarem in their behavior and highly respect perarem as the legal product of customary village. Therefore, it is highly appropriate to collaborate in preventing drug abuse especially in Bali by inserting rules about drug into awig-awig or perarem. Although it has been regulated by the Act of AntiNarcotics, if the implementation is synergized into all customary villages, so the impact will be maximum. Based on the interview with some informants (customary figures), they agreed to insert the regulation about drugs abuse and circulation into perarem, as stated by The Head of Bali Office of National Anti-Narcotics Agency (25-05-2018): Contribution and special attention of the people related to drugs circulation prevention highly needs the role of the Head of Village and village officers who run the function of village territory safety and the villagers' prosperity, of which are very strategic considering the drugs circulation has reached village and various layers of society. One of the efforts that can be done is supporting the customary village to make perarem about Prevention, Eradication, Abuse and Illegal Circulation of Narcotics.

The statement of the Head of Bali Office of National Anti-Narcotics Agency is positively welcomed by people figures of Plagan Customary Village, Denpasar Timur District, Denpasar City, 08-05-2018, who stated that : To maintain safety of our territory from negative influences as the impact of Bali being the tourism destination especially for the young generation as the nations' successor not to be involved or use drugs so I highly agree and soon insert regulation about drugs into our perarem in our customary village.

Another support was also delivered by other informant of Vice Bendesa of Gerih Customary Village, Abiasemal District, Badung Regency, Bali Province (02-06-2018), who stated that:

To anticipate that our area free from circulation and abuse of drugs, there will be pesangkepan or paruman (meeting) with all of our krama (people) to talk about the importance of the existence of written regulation to manage this issue in form of perarem.

In this pararem of Banjar Adat Sampiang, the prohibition of drug abuse is stated in Chapter XIX concerning prohibition. Specifically, it is regulated in Article 72 paragraph 8 which state that every krama (member) of Banjar Adat Sampiang or other people are prohibited to keep, use and circulate drug. The sanction is regulated in the next sheet, that anyone who violates Article 8 paragraph 72 can be fined IDR 500.000 and conduct prascita gumi ceremony, as the guidance of the sulinggih (priest), concerning the place and time is determined by the Officer of Sampiang. 
It is needed to insert prohibition of drug abuse into perarem because Balinese people highly trust and depend or fear the awig-awig or pararem besides obeying the legal formal of Indonesia. It is because perarem besides regulating sanction in form of money, it also regulates social sanction, depending on the level of violation in which the most major sanction is kasepekkang (expelled from their village). This social sanction makes Balinese people obey and conduct awig-awig or pararem as the customary law in Bali.

\section{CONCLUSION}

In order to minimize the drugs circulation and abuse in Indonesia, especially in Bali, this effort should be done not only by government which is represented by BNNP or BNNK but also all people. For preventive effort, there should be collaboration between BNNP with local wisdom such as customary village which has legal product called as awigawig or pararem because these legal products contain sanction for the abuse, in which the most severe punishment is kesepekang (expelled from the village).

\section{REFERENCES}

[1] Sri Purwatiningsih, Populasi, jurnal kependudukan dan kebijakan,Universitas Gajah Mada, Vol.12.No.1, 2001.

[2] Jimmy Simangunsong, Penyalahgunaan Narkoba Di Kalangan Remaja (Studi kasus pada Badan Narkotika Nasional Kota Tanjungpinang EJurnal Program Studi Ilmu Sosiologi Fakultas Ilmu Sosial Dan Politik Universitas Maritim Raja Ali Haji Tanjungpinang 2015.

[3] Maudy Pritha Amanda , Sahadi Humaedi ,and Meilanny Budiarti Santoso, Penyalahgunaan Narkoba Di Kalangan Remaja (Adolescent Substance Abuse), Jurnal Penelitian \& PPM Universitas Padjadjaran, ISSN: 2442-448X Vol 4, No: 2 pp: 129 - 389, 2017

[4] Tri Wibawan, Bahaya Narkoba Dikalangan Remaja, Jurnal Ilmiah Jurusan Teknologi Pendidikan Fakultas Ilmu Pendidikan, Universitas Negeri Semarang.

[5] Dewi Anggreni, Dampak Bagi Pengguna Narkotika, Psikotropika Dan Zat Adiktif (Napza) Di Kelurahan Gunung Kelua Samarinda Ulu. ejournal.sos.fisip-unmul,2015.

[6] $[6,10,11,16]$ Abdulsyani, Sosiologi Skematika, Teori, dan Terapan. Jakarta: Bumi Aksara, 2004.

[7] Hadari Nawawi, 1984, Administrasi Pendidikan.Jakarta: Gunung Agug,1984.
[8] Abu Ahmadi, Sosiologi Pendidikan. Jakarta : PT. Rebnika Cipta,2004.

[9] J, Dwi Narwoko, 2004, Sosiologi Teks Pengantar dan Terapan. Jakarta: Prenada Media.

[10] Jenny Weinstein, ColinWhittingtonand Tony Leiba : Collaboration in Social Work Practice . Jessica Kingsley Publishers : London and New York, 2003

[11] Erik van Ommeren,Sander Duivestein, John deVadoss,Clemens Reijnen and Erik Gunvaldson. Collaboration in the Cloud. How CrossBoundary Collaboration Is Transforming Business. Microsoft and Sogeti, 2009.

[12] Bhuvan Unhelkar,Abbass Ghanbary, and Houman Younessi. Collaborative Business Process Engineering and Global Organizations:Frameworks for Service Integration. Published in the United States of America by Business Science Reference (an imprint of IGI Global), 2010

[13] Hall, E. T., \& Hall, M. R. Understanding cultural differences: Germans,French, and Americans. Yarmouth, ME: International Cultural Press, 1990

[14] Astiti, Tjok Istri Putra, Pemberdayaan Awig-awig Menuju Ajeg Bali,Lembaga Dokumentasi dan Publikasi Hukum Universitas Udayana, 2005.

[15] Barbara Kożuch : The Culture of Collaboration. Theoretical Aspects. Journal of Intercultural Management Vol. 1, No. 2, November 2009

[16] Hunger, F.W.F, 1982, Desa Adat dan Desa Pemerintahan. (terjemahan I Wayan Dangin), tanpa nama dan alamat penerbit.

[17] Parimartha, I Gde, "Memahami Desa Adat, Desa Dinas dan Desa Parwata, AA Gede Oka, 2007, "Memahami Awig-awig Desa Pakraman”, dalam I Ketut Sudantra dan AA Gede Oka Parwata (ed): Wicara Lan Pamidanda, Pemberdayaan Desa Pakraman dalam Penyelesaian Perkara Di Luar Pengadilan, Upada Sastra Denpasar Pakraman (Suatu Tinjauan Historis Kritis)", orasi ilmiah, Universitas Udayana, Kampus Bukit Jimbaran, 2003.

[18] Sudantra I Ketut, 2007, "Pelaksanaan Fungsi Hakim Perdamaian Desa dalam Kondisi Dualisme Pemerintahan Desa Di Bali”, Tesis Program Magister Ilmu Hukum Program Pascasarjana Universitas Udayana.

[19] Institut Hindu Dharma, 1996, Keputusan Seminar XII Kesatuan Tafsir Terhadap Aspek-aspek Agama Hindu, Proyek Daerah Tingkat I Bali.

[20] T. Anisa Pitri dan Khairul Anwar, Kolaborasi Pemerintah Dan asyarakat Dalam Penyelenggaraan Pendidikan: Pendidikan Khusus Di Provinsi Riau Tahun 2015-2016. Jom FISIP Universitas Riau Volume 4 No. 2 Oktober 2017

[21] UU Nomor 35 tahun 2009 tentang Narkoba

[22] Peraturan Daerah Provinsi Bali Nomor 3 Tahun 2001, jo. Nomor 3 Tahun 2003 tentang Desa Pakraman 